\title{
Students' teaching practice of bachelor's degree linguists as an essential stage in implementation and improvement of professional competences
}

\author{
A.S. Yagubova ${ }^{1 *}, M . V$. Murieva $^{2}$, and L.F. Dzilikhova ${ }^{3}$ \\ ${ }^{1}$ North Ossetian State University, Vladikavkaz, Russia \\ ${ }^{2}$ North Ossetian State University, Vladikavkaz, Russia \\ ${ }^{3}$ Financial University, Vladikavkaz, Russia
}

\begin{abstract}
One of the most important purposes of Higher Education is to train highly competent specialists, to provide high quality education as a result of mastering educational programs in accord with the requirements of Federal State Educational Standard (FSES) of Higher Education. This purpose is the key point in the work of any Institution of Higher Education. Modern competences paradigm of Higher Education (bachelor's degree) is directed to form the following types of competences: general cultural competences (gcc), general professional competences (gpc) and professional competences (pc) which are presented in the working programs of the faculties or departments the subjects are taught by. In the set of compulsory subjects there is Working (teaching) practice of Bachelor's degree Linguists which is held in secondary general education schools. This kind of practical education is considered by teachers, psychologists and scientists-methodologists as one of the most significant stages in training teachers which leads to improving professional competences of students-linguists - future foreign language teachers. In this article we pay attention to investigation of professional competencies of linguists - future foreign language teachers. It is in the course of teaching practice that future specialists have opportunities to demonstrate knowledge, skills and abilities, to implements and improve their professional competences.
\end{abstract}

\section{A problem statement}

It is indisputable fact that students' teaching practice is and has always been the essential part of teacher training curriculum. Students' teaching practice in secondary general education schools is one of the most important segments of professional training of future teachers. This type of practice is the link between theoretical education at the university and independent work of students during teaching practice at schools where students perform functions of both subject teachers and class teachers. During teaching practice students

* Corresponding author: prof-ped.gpa@mail.ru 
study the basics of their future profession, learn professional competences that lay the foundation of educational process of future teachers. Therefore, attention should be paid to organization of teaching practice, to teaching support and yo the choice of secondary general education schools as teaching practice base.

In wide sense "practice" is a real activity of people aimed at development and progress of society. The word "practice" - "praktikos" is of Greek origin. It is used by teachers and methodology-scientists in the applied meaning. In "Explanatory Dictionary of the Russian Language" by S.I. Ozhegov, N.Yu. Shvedova "practice" has the following meaning people's activity in the course of which they transform the material world and society by influencing them. Unity of theory and practice". Thus, students' teaching practice has activity-based character and is aimed at immersion in the future profession, at acquisition of teaching practice experience at schools while working as a foreign language teacher and a class teacher. Moreover, it is teaching practice that leads to correcting and perfecting professional competencies that have been formed during the training period at the university. Competences as a unity of individual and professional features were analyzed by foreign and domestic authors V.I. Baidenko, A.V. Bolotov, E.F. Zeer, I.A. Zimnya, I.Ya. Lerner, V.V. Krayevsky, M.N. Skatkin, B.A. Takhokhov, B.D. Elkonin, A.V. Khutorsky, G.P. Schedrovitsky, R. Page, G. Sartan, S. Spencer and many others. Problems of students' teacher training were discussed by K.D. Ushinsky, V.A. Sukhomlinsky, V.G. Ananiev, M.V. Bulanova-Toporkova, S.I. Gessen, K. Platonov, V.A. Slastenin, V.D. Shadrikov, A.A. Verbitsky, S.I. Gessen et al. Questions of organizing and conducting practical training of future teachers have been reflected in the works of scientists-researchers S.T. Shatsky, T.A. Volkova, T.N. Dobronravova, K.I. Salomatov, I.G. Sedova, M.V. Murieva et al. Nowadays students' teacher training is still under investigation due to modern challenges.

\subsection{The objective of the work}

The above stated problem is reflected in the works of many domestic and foreign authors. Nevertheless, the subject of students' teaching practice and formation of professional competences is not investigated thoroughly, though a number of authors discussed this issue in their works [1-9]. A good amount of attention is also given to teaching methods which is undoubtedly extremely important. In their works many authors also discuss the importance of students' teaching practice:

1."student teachers are expected to give their best in teaching students as it is time to showcase skills gained from theoretical course" [10];

2."proficiency in professional and methodological skills and competences enables a teacher to preserve an inseparable link between theory and teaching practice" [11];

3. "...it is necessary for a student to possess professional-methodological competence which is the nuclear element of his proficiency" [12];

4. “...the psychological and pedagogical support of the student's personality" is very important [13];

5. "...teachers face a lot of problems in teaching students, new requirements of the multicultural world" [14];

6." ...students are future teachers who must be ready to implement the educational process" [15];

7. “... students' teaching practice is the most efficient means of preparation of teachers for their professional-communicative activity" [16].

In accordance with the working program of the discipline "Teaching practice" (Linguistics "Theory and practice of intercultural communication" Bachelor's degree) the purpose of teaching practice is to form special students' competences specified in Federal State Educational Standard of Higher education corresponding to the particular field of 
study, skills and abilities of organization and creative comprehension of educational process. Initial objective of Teaching Practice consists in preparation of bachelor's degree linguists for competent implementation of teaching activity in secondary general education schools and institutions of secondary vocational education which is based on the combined pedagogical, psychological and I-T knowledge. Some researchers see "the main goal in providing future foreign language teachers with high-tech material explaining the most important methodological phenomena in the system, and laying the foundation for theoretical training in their speciality" [17]. Students' teaching practice helps to solve the following fundamental problems of professional psychological-pedagogical activity:

In the field of teaching:

- advanced study of the whole system of psychological-pedagogical process in secondary general education schools;

- $\quad$ education in accord with Federal State Educational Standard of Higher education.

In the field of methodology:

- $\quad$ mastering teaching methods and pedagogical skills;

- $\quad$ forming abilities to prepare educational and methodological material on different subjects;

- forming skills to conduct an expert examination of individual sections of methodological system of education;

- $\quad$ mastering using computer technologies in various types of educational institutions

To master this practice a trainee must:

know:

- the main theoretical issues of modern foreign language teaching methods and related sciences that define the organization and foreign language process in secondary comprehensive schools;

be able to:

- $\quad$ navigate modern methodological literature, make choice of manuals, textbooks and other tools in accord with the situation;

plan foreign language educational process in line with the aims stated in the program, taking into account the conditions of learning;

arrange the course of foreign language teaching at various stages using modern educational and methodical complexes, manuals and other tools including I-T technologies in accordance with the aim stated;

posses:

- modern knowledge of a foreign language part in the system of Linguistic education at school, about peculiarities of foreign language teaching in the multilingual and multicultural world.

\section{Results of the research}

In the course of pedagogical practice linguistic students (students of linguistic faculties) use knowledge, skills, methods of activity and attitudes formed in the course of studying disciplines from the fields of knowledge mastered in the process of the main educational program (MEP) of higher education: "Practical Course of the First Foreign Language", "Practice of Verbal Communication", "Methods of Teaching Foreign Languages", "Lexicology", "Stylistics", "Practical Grammar", "Multimedia and Technical Teaching Aids", " Theory of Translation ", "History and Culture of the Country of the Target Language", "Basics of the Theory of Intercultural Communication ", etc. Much attention is paid to the studying of such disciplines as "Developmental Psychology" and "Pedagogy". According to the curriculum the organization and conducting of pedagogical practice for 
linguists studying for their bachelor degree, future foreign language teachers, take place in the 8th semester (term) (Table 1).

Teaching practice is aimed at the formation of the following necessary professional competencies, which are highlighted by the authors of the work program for this discipline:

Table 1. Professional competences, formed by the teaching of linguists studying for their bachelor degree.

\begin{tabular}{|l|l|}
\hline \multicolumn{1}{|c|}{ Professional competences (PC) } \\
\hline \multicolumn{1}{|c|}{ Linguodidactic activity: } \\
\hline PC-1 & $\begin{array}{l}\text { possession of the theoretical basics in teaching foreign languages, the laws governing } \\
\text { the formation of ability for intercultural communication; }\end{array}$ \\
\hline PC-2 & $\begin{array}{l}\text { possession of the means and methods of a teacher's professional activity, as well as } \\
\text { the patterns of teaching and learning foreign languages; }\end{array}$ \\
\hline PC-3 & $\begin{array}{l}\text { the ability to use textbooks, teaching aids and didactic materials in a foreign language } \\
\text { to develop new teaching materials on a specific topic; }\end{array}$ \\
\hline PC-4 & $\begin{array}{l}\text { the ability to use the achievements of domestic and foreign methodological heritage, } \\
\text { modern methodological directions and concepts of teaching foreign languages for } \\
\text { solving specific methodological problems of practical nature; }\end{array}$ \\
\hline PC-5 & $\begin{array}{l}\text { the ability to analyze the educational process and teaching materials critically in terms } \\
\text { of their effectiveness; }\end{array}$ \\
\hline PC-6 & $\begin{array}{l}\text { the ability to build the educational process effectively, carrying out pedagogical } \\
\text { secondary general and secondary vocational education, as well as additional linguistic } \\
\text { education (including additional education for children and adults and additional } \\
\text { vocational education) in accordance with the tasks of a specific educational course and } \\
\text { conditions of teaching foreign languages. }\end{array}$ \\
\hline PC-23 & $\begin{array}{l}\text { the ability to use the conceptual apparatus of philosophy, theoretical and applied } \\
\text { linguistics, translation studies, linguodidactics and the theory of intercultural } \\
\text { communication to solve professional problems; }\end{array}$ \\
\hline PC-24 & $\begin{array}{l}\text { the ability to generate hypotheses and develop argumentation consistently in their } \\
\text { defense. }\end{array}$ \\
\hline
\end{tabular}

As you can see from the table, professional competencies are implemented in two types of activities (Table 1):

1) linguodidactic (6);

2) students's research activities (2).

N.B. Izotova points out that "the most difficult for formation are the professional and special competences peculiar for the profile of education of a future teacher" [16] as they need profound insight and understanding based on students' motivation that teachers can strengthen in various ways: E.g. problematization of educational process; creativity. In addition to these competences students "acquire intercultural competences that are inseparable from foreign language learning" [18] as the main goal that a person achieves while learning a foreign language is to get acquainted with the foreign language culture and to communicate with people from other countries in various ways: writing, listening, speaking.

At the Teacher Training Department with two profiles: "a Foreign language (English) and Russian as a Foreign Language" students have Teaching practice every year of their studies. During the first year students have Introductory Teaching Practice (English) in the course of which they get acquainted with the structure of educational process at school. They attend lessons, try to analyze them. Subject teachers show the students how to plan a foreign language lesson, what parts a lesson should consist of. We may call this practice 
"an observation period" for junior students that helps students to obtain school-based experience. "To plan and construct a lesson, to conduct and analyze a lesson means to solve a complex task." [19] Moreover, students help class teachers in organizing extra-curricular work. Such kind of work "helps to create experience that will remain with the students for a long period of time" [20] In addition this practice is useful for first year students as most of them have not yet decided what profession to take up. At the beginning of the academic year only $15 \%$ of students consider teaching as their future profession. About $85 \%$ of students have no confidence. After the Introductory practice about 50\% students claim that they will work as teachers and $50 \%$ still are not convinced. The same type of practice is conducted during the second year - Introductory Teaching Practice (Russian): students get acquainted with the professional duties and responsibilities of the Russian Language teacher at a secondary general education school. Students' teaching practice starts in the fourth year when students have already learned a number of theoretical courses in teaching methods, psychology and some others that will enable them to better understand their future work. The teacher training department students develop not only professional competences (like Linguists) they also acquire universal competences some of which are aimed at managing projects, using modern IT technologies in the educational process, performing critical analysis of some problematic situations., During teaching practice students observe lessons of experienced teachers, discuss them with their tutors and commence planning and conducting lessons on their own. Senior students spend about 14 weeks on teaching practice. About $85 \%$ of under graduates state that they become more confident in choosing $\mathrm{s}$ career after students' teaching practice that they consider as positive experience in the course of education at the university that improve and deepen their theoretical preparation and give an idea of their future work. It should be noted that a special role is given to a supervisor or a tutor on teaching practice who explains to the students their possible mistakes and supports the students giving them advice and sharing knowledge.

Students represent a specific community of young people between 17 and 22 years of age studying at universities in order to acquire knowledge, professional skills and abilities in the chosen specialty and having a formed positive attitude towards their future profession. Scientists consider this age as the peak of human cognitive and intellectual capabilities. Such qualities as perseverance, commitment, the ability to control oneself, initiative, independence, making responsible decisions, etc., can be seen in young people precisely in this age period (V.G. Ananiev, A.V. Dmitriev, V.T. Lisovsky, L.D. Stolyarenko and others). According to V.G. Ananyev and K. Platonov, "the formation of human personality occurs directly in professional activity and under its influence" [21].

The development and formation of necessary general cultural competencies (GCC), general professional competences (GPC), professional competences (PC) of students begins at the university, where they are involved not only in active educational but also organizational, creative and research activities, which contribute to the strengthening of faith in the correct choice of future professional activities. However, the main figure of the university educational process is a teacher who can organize the acquisition of knowledge by students effectively, making them subjects of the pedagogical process. At this point it seems appropriate to emphasize the role of the competence-based approach, which puts forward the students' professional competencies as a set of interrelated orientations, skills, abilities, knowledge and experience of activities necessary for the implementation of personally and socially significant productive practical activity in real life. In addition, personality-orientated approach is of great value as teachers should take into consideration peculiarities of every student and help them find their own way in future profession.

Successful mastering of the discipline "Methods of Teaching Foreign Language" guarantees the students' theoretical readiness for the upcoming pedagogical practice at SEI (Secondary Educational Institution). At the end of the course, role-playing and business 
games are conducted, which are preceded by preparatory work. Role-playing games involve students playing out fragments of a lesson in foreign language according to the pre-assigned roles, where the teacher is an outside observer. The business game "My Profession Is a Teacher" is aimed at acquiring the first experience of future professional activity. It is organized by the teacher and also requires a lot of preparatory work. "Thanks to its symbolic character a game gives unlimited opportunities to create fictional situations, problems, incidents, conflicts - everything that requires verbal and non-verbal activity" [22]. Thus, in the field of linguodidactic activity, all professional competencies indicated in the table are formed at the university, receiving practical implementation and correction in the course of pedagogical practice. преподавателем и также требует большой подготовительной работы.

Preparation and participation in various annual events plays an important role in students' lives. These are: a mourning event in early September "Day of Remembrance of the Victims in Beslan", "Dedication to Students", "Teacher's Day", "World Translator Day", "Green Apple", "World Poetry Day", "Student Spring", "Victory Day at NOSU", interfaculty and interuniversity sports competitions, Brain-ring, etc. Students with their teachers are involved in organizing and actively participating in career guidance work of the university and faculty.

As for research activities, students take part in events such as "Science Day at NOSU", various competitions, interuniversity Olympiads, intellectual games, scientific conferences at regional, national and international levels, including those organized by the Ministry of Education and Science of the Russian Federation.

For a few years, the authors of this article have been group leaders of students of the Faculty of Foreign Languages of the Federal State Budgetary Educational Institution of Higher Education "North Ossetian State University named after K.L. Khetagurov" during their pedagogical practice. As a rule, we begin our practice by holding an orientation conference, explaining to the students its goals, objectives and requirements for them. It is no secret that in recent decades, unfortunately, the teaching profession, including teaching foreign languages, has not been prestigious. In order to identify the willingness of graduate students to work in the chosen specialty, we conduct a survey twice: before passing pedagogical practice and after it. The first part of the survey conducted in 2017-2020 (4853 participants) revealed that:

1) $10-13 \%$ of graduate students already work as foreign language teachers;

2) $37-41 \%$ have not yet decided whether they are ready to link their professional activities to teaching and educational activities in educational institution;

3) The rest of the respondents - 46-53\% showed a desire to engage in teaching activities.

Hereinafter, we provide generalized survey data for the period from 2017 to 2020 .

A survey conducted at the Faculty of Foreign Languages after completing pedagogical practice showed that:

1) $10-13 \%$ of graduate students are already working as teachers of foreign languages, combining their studies at the university with the work at a special educational institution, and would like to continue this activity after graduating from the university;

2) $28-30 \%$ of the survey participants would not want to work at a special educational institution as foreign language teachers in view of the low salary and great responsibility for children;

3) $70-72 \%$ of the respondents (including the first $10-13 \%$ ) showed a desire to work in an educational institution or vocational education system, because they like to teach foreign languages to children and teenagers, and they do not have problems in communicating with them.

If we compare the numbers, we can see that the results of the survey before pedagogical practice and after it differ sharply. The students explained this by the fact that they had 
anxiety and fear of children at first. However, by the end of the practice, they were already freely giving lessons feeling confident in their abilities and the joy of communicating with pupils. M.V. Murieva notes that "Parents make a mistake when they force their children to take up a profession that does not suit them or even contradicts their aspirations, in the long run it may affect professional development of a character in the negative way" [23].

It should also be added that successful and productive educational activities are impossible without love for children and their profession, without the desire to do good and shape personalities. According to V.A. Krutetsky, it is also necessary to have propensity for pedagogical activity and the desire and ability to work and communicate with children.

\section{Conclusions}

Being an inseparable part of teacher training, students' teaching practice occupies an important place in educational process at the university. Pedagogical (teaching) practice is based on both theoretical courses and practical education and prepares good teachers. To summarize we can add that firstly, during the pedagogical practice linguistic students realize the potential of professional competencies that was formed during their studies at the university. Secondly, in the course of real practical activity the students get an opportunity to improve their knowledge, skills and abilities, to plan and build an effective learning process for foreign language. We believe that the first valuable practical experience of teaching and educational activities, received by our students - future teachers of foreign languages - in the course of pedagogical practice, is one of the most important stages in self-improvement of a future specialist, the opportunity to hone their pedagogical skills, correct and improve professional pedagogical competencies.

\section{References}

1. A.V. Skvortsov, T.S. Komissarova, Professional creative skills of subject teachers as a condition for formation of creative abilities of students, Bulletin of the Pushkin Leningrad State University, 42, 173-180 (2016)

2. O.V. Surmentova, The role of the student self-government in formation of the general cultural and professional competences of students, Bulletin of NSTU named after R.E. Alekseev, 1, 37-40 (2015)

3. I.V. Rudenko, The formation of general professional competences of bachelors in the student self-government activities as a subject of educational activities of the university, Kazan Pedagogical Journal, 4, 273-278 (2015)

4. S.V. Ginne, To the question of the formation of professional competencies of the future bachelor, Problems of modern pedagogical education, Series: Pedagogy and psychology, 52(5), 157-164 (2016)

5. S.V. Ginne, On the formation of professional competencies of the future bachelor, International Research Journal, 5(47), 16-18 (2016)

6. S.V. Ginne, On the main stages of professional competencies of the future bachelor in a technical university, Problems of modern pedagogical education, 6(2), 90-93 (2020)

7. S.V. Ginne, The future bachelor of science as a subject of development of professional competencies, Business Education Law, 3(52), 438-444 (2020)

8. O.P. Mikhanova, General cultural competencies: diagnostics (part II), Volga region. Series: Humanitarian Sciences, 2(42), 23-34 (2017) 
9. M.F. Mrtinez et al., Training of teachers and assessment of their performance on the basis of the competency-based approach, Integration of Education, 23(3), 350-365 (2019)

1. 10.Ben de Sousa, Rhodes University, Teaching Practice A Handbook for Student Teachers (2015)

10. A.Yu. Shvatsky, Preparation of a future foreign language teacher for teaching languages and cultures (2019)

11. N.D. Gal'skova, A.P. Vasilevich, N.F. Koryakovtseva, N.V. Akimova, The Basics of Learning Foreign Languages. Text-book (2018)

12. A.V. Pryakhina, M.V. Sozinova, Psychological and pedagogical support of professional development of the personality of a student at the University, Business Education Law, 1 (2020)

13. A.S. Yagubova, Teaching language abilities and speaking skills by means of virtual travelling, Business Education Law, 3, 417-422 (2020)

14. E.V. Korotkova, E.A. Tsaregorodskaya, Potential of interactive lessons in competence-based approach to training teachers, Modern problems of science and education, 1 (2020)

15. N.B. Izotova, Educational Linguistic Practice as a basis for formation of professional-communicative competences of a Foreign Language Teacher, Modern problems of science and education, 1 (2015)

16. A.M. Dzhakan, G.A. Abdimaulen, Techniques of Teaching English (As a Second Language) at School (2019)

17. A.S. Yagubova, M.V. Murieva, Linguocultural Approach As Modern Experience in Learning Foreign Languages, The European Proceedings of Social and Behavioural Sciences, 214, 1841-1849 (2018)

18. T.I. Skripnikova, Theoretical basis of foreign language teaching methods (2017)

19. G.V. Glukhov, Yu.D. Ermakova, I.V. Kapustina, New tendencies in Foreign Language Teaching, Bulletin of Samara State University, 2(38) (2018)

20. B.G. Ananiev, Selected Psychological Works: in 2 volumes (1990)

21. M.V. Murieva, Gaming Technologies in modern foreign language education, Problems of modern pedagogical education, 56-9, 158 (2017)

22. M.V. Murieva, Students' Teaching Practice as a stage in professional formation of students - future foreign language teachers, Vector of science Tolyatti State University, 4(19), 124 (2014) 